$\begin{array}{lllllllllll}\mathbf{T} & \mathbf{L} & \mathbf{U} & \mathbf{M} & \mathbf{A} & \mathbf{C} & \mathrm{Z} & \mathbf{E} & \mathbf{N} & \mathbf{I} & \mathbf{A}\end{array}$

[1]

Zeszyty Prawnicze

21.2 / 2021, s. 325-343

DOI 10.21697/zp.2021.21.2.15

MONUMENTA AERE PERENNIORA

\author{
WiKTORIA SARACYN
}

Uniwersytet Warszawski

\title{
O NAJWYŻSZEJ TRÓJCY I O WIERZE KATOLICKIEJ I O TYM, ABY NIKT O NIEJ NIE OŚMIELIŁ SIE PUBLICZNIE DYSKUTOWAĆ. 8 FRAGMENT 1 TYTUŁU 1 KSIĘGI KODEKSU JUSTYNIAŃSKIEGO
}

Pochodząca z lat 533-534 n.e. korespondencja cesarza Justyniana I i papieża Jana II została włączona do nowelizowanego na mocy konsty tucji Cordi Kodeksu Justyniana. Już jako tekst o charakterze normatywnym znalazła miejsce w 1 księdze Kodeksu, w 8 fragmencie 1 tytułu De summa Trinitate et ut nemo de ea publice contendere audeat. Nieprzypadkowo, bowiem zawarte w niej treści są wspaniałym obrazem justyniańskiej polityki wyznaniowej na tle sporów doktrynalnych będących głównym przedmiotem obrad wielkich soborów powszechnych. 
8 pr. Gloriosissimo et clementissimo filio Iustiniano Augusto, Iohannes Episcopus. Inter claras sapientiae mansuetudinis vestrae laudes, christianissime principum, puriore luce tamquam aliquod sidus irradiat, quod amore fidei, quod caritatis studio, edocti ecclesiasticis disciplinis, Romanae sedis reverentiam conservatis et ei cuncta subicitis et ad eius deducitis unitatem, ad cuius auctorem, hoc est apostolorum primum, domino loquente praeceptum est: 'pasce oves meas'.

1. Quam esse omnium vere ecclesiarum caput et patrum regulae et principum statuta declarant et pietatis vestrae reverentissimi testantur affatus. Patet igitur in vobis impletum fore, quod scripturae loquuntur: 'per me reges regnant et potentes scribunt iustitiam'.

2. Nihil est enim, quod lumine clariore praefulgeat, quam recta fides in principe, nihil est, quod ita nequeat occasui subiacere, quam vera religio. Nam cum auctorem vitae vel luminis utraque respiciant, recte et tenebras respuunt et nesciunt subiacere defectui.

3. Quam ob rem, gloriosissime principum, votis omnibus exorabitur divina potentia, ut pietatem vestram in hoc ardore fidei, in hac devotione mentis, in hoc integrae religionis studio sine defectu sui in tempora longiora conservet: hoc enim et sanctis credimus ecclesiis expedire. Scriptum est enim: 'labiis regit rex', et iterum: 'cor regis in manu dei, et ubi voluerit, inclinabit illud'.

4. Hoc est enim, quod vestrum firmat imperium, hoc, quod vestra regna conservat. Nam pax ecclesiae, religionis unitas, auctorem facti in sublime provectum grata sibi tranquillitate custodit.

5. Neque enim parva ei vicissitudo a potentia divina tribuitur, per quem nullis rugis ecclesia divisa secernitur, nullis insertis maculis variatur. Scriptum est enim: 'quia cum rex iustus sederit supra sedem, non adversabitur ei quicquam malignum'.

6. Proinde serenitatis vestrae apices per Hypatium atque Demetrium sanctissimos viros fratres et coepiscopos meos reverentia consueta suscepimus: quorum etiam relatione comperimus, quod fidelibus populis proposuissetis edictum amore fidei pro submovenda haereticorum intentione secundum apostolicam doctrinam, fratrum et coepiscoporum nostrorum interveniente consensu. Quod, quia apostolicae doctrinae convenit, nostra auctoritate confirmamus. 
Najdostojniejszemu i Najłagodniejszemu Synowi Justynianowi Augustowi, Jan Biskup. Spośród znakomitych zasług mądrości Waszej Łaskawości, Najbardziej Chrześcijański z Władców, jasnym światłem, jako gwiazda, świeci (to), że poprzez miłość do wiary i gorliwe miłosierdzie zgłębiwszy nauczanie Kościoła, zachowałeś szacunek dla Stolicy Rzymskiej, wszystko jej ofiarowałeś i jedność zaprowadziłeś do niej, której sprawcy, to jest Pierwszemu z Apostołów słowami Pana zostało przykazane „Paś owce moje” [J 21,17].

1. O tym, że jest ona [Stolica Apostolska] prawdziwie głową wszystkich kościołów, świadczą prawa ojców i konstytucje władców, a także wielce czcigodne dekrety Waszej Litości. Jest przeto oczywiste, że wypełni się w Was (to), co zostało powiedziane w Piśmie: „Ze względu na mnie panują królowie, a władcy piszą sprawiedliwość" [Prz 8,15; przekład według Biblii Tysiąclecia: „a możnowładcy sprawiedliwie wyrokują"].

2. Nie ma bowiem nic, co jaśniałoby większym blaskiem niż prawdziwa wiara u władcy, nie ma nic równie niemożliwego do zniweczenia, co prawdziwa religia. Gdy bowiem obie [stolice: Rzym i Konstantynopol] mają wzgląd na Twórcę Życia i Światłości, (wtedy to) należycie wyzbywają się ciemności i nie wiedzą, co znaczy ulegać słabościom.

3. Z tego też powodu, Najdostojniejszy z Władców, będziemy wypraszać Boską Potęgę we wszystkich modlitwach, aby Waszą Litość w tym ogniu wiary, w tej pobożności umysłu, w tej gorliwości czystej religii przez długie lata bez uszczerbku zachowała; wierzymy bowiem, że przysłuży się to także świętym Kościołom. Jest bowiem napisane: „Król króluje poprzez usta” [Prz 16,10], i dalej: „Serce króla (spoczywa) w dłoni Boga, (a On) gdzie zechce, tam je obróci” [Prz 21,1].

4. Jest to zatem (to), co utwierdza Waszą władzę, to, co utrzymuje Wasze rządy. Albowiem pokój Kościoła, jedność religii, wdzięczne za swój ład, strzegą, aby ich sprawca został (po śmierci) w górę wywyższony.

5. Lecz Boska Potęga nie okazuje ani nawet najmniejszej wdzięczności temu, z czyjej przyczyny żadnymi pęknięciami nie został Kościół podzielony ani żadnymi skazami splamiony. Jest bowiem napisane: „Ponieważ gdy król sprawiedliwy zasiądzie na tronie, nie wzruszy go żadne zło" [Prz 20,8].

6. Ponadto z należytą czcią otrzymaliśmy list Waszej Miłości od Hypatiusza i Demetriusza [legatów Justyniana], przeświętych mężów, braci 
7. Textus autem epistulae talis est: Victor Iustinianus Pius Felix Inclitus Triumphator Semper Augustus Iohanni Sanctissimo Archiepiscopo Almae Urbis Romae et Patriarchae

8. Reddentes honorem apostolicae sedi et vestrae sanctitati, quod semper nobis in voto fuit et est, ut decet, patrem honorantes vestram beatitudinem omnia, quae ad ecclesiarum statum pertinent, festinamus ad notitiam deferre vestrae sanctitatis, quoniam semper magnum nobis fuit studium unitatem vestrae apostolicae sedis et statum sanctarum dei ecclesiarum custodiri, qui hactenus obtinet et incommote permanet nulla intercedente contrarietate.

9. Ideoque omnes sacerdotes universi Orientalis tractus et subicere et unire sedi vestrae sanctitatis properavimus.

10. Et in praesenti ergo quae hic commota sunt, quamvis manifesta et indubitata sint et secundum apostolicae vestrae sedis doctrinam ab omnibus semper sacerdotibus firme custodita et praedicata, necessarium duximus, ut ad notitiam vestrae sanctitatis perveniant.

11. Nec enim patimur quicquam, quod ad ecclesiarum statum pertinet, quamvis manifestum et indubitatum sit, quod movetur, ut non etiam vestrae innotescat sanctitati, quia caput est omnium sanctarum ecclesiarum. Per omnia enim, ut dictum est, properamus honorem et auctoritatem crescere vestrae sedis.

12. Manifestum igitur facimus vestrae sanctitati, quod pauci quidam infideles et alieni sanctae dei catholicae atque apostolicae ecclesiae contradicere iudaice ausi sunt adversus ea, quae ab omnibus sacerdotibus secundum vestram doctrinam recte tenentur et glorificantur atque praedicantur, denegantes dominum nostrum Ihesum Christum, unigenitum filium dei et deum nostrum, incarnatum ex sancto spiritu et sancta atque gloriosa virgine et dei genetrice Maria hominem factum atque crucifixum, unum esse sanctae et consubstantialis trinitatis, coadorandum et conglorificandum patri et spiritui sancto, consubstantialem patri secundum divinitatem et consubstantialem nobis eundem ipsum secundum humanitatem, passibilem carne, eundem ipsum impassibilem deitate.

13. Recusantes enim dominum nostrum Ihesum Christum unigenitum filium dei et deum nostrum fateri unum esse sanctae et consubstantialis trinitatis videntur nestorii malam sequentes doctrinam, 
i współbiskupów moich: Dowiedzieliśmy się także z ich relacji, że w ogniu miłości, zgodnie z nauczaniem Kościoła i w porozumieniu z naszymi braćmi i współbiskupami wydaliście wiernym edykt, ku zniweczeniu (wszelkich) dążeń heretyków. Ponieważ jest on zgodny z nauczaniem Kościoła, na mocy naszej władzy (wszystko, co w nim zawarte) potwierdzamy.

7. Taki oto jest tekst listu: Zwycięski Justynian Łaskawy Szczęśliwy Sławny Triumfator zawsze Augustus, Janowi, Najświętszemu Arcybiskupowi i Patriarsze Czcigodnego miasta Rzymu.

8. Oddając honory Stolicy Apostolskiej i Waszej Świętobliwości, co zawsze było i jest naszą wolą i co należy czynić, czcząc Waszą Wielebność jak Ojca, spieszymy donieść do wiadomości Waszej Świętobliwości wszystko, co dotyczy pozycji Kościołów. (Od) zawsze wielce istotne było dla nas dążenie do jedności Waszej Stolicy Apostolskiej i stanie na straży pozycji Świętych Kościołów Bożych, co aż do tej pory niewzruszenie trwało bez żadnych przeciwności.

9. Dlatego też spieszyliśmy, aby wszyscy duchowni Świata Wschodniego poddali się Wam i złączyli z Waszą Stolicą.

10. Uznaliśmy zatem za konieczne, aby zostały doniesione do wiadomości Waszej Świętobliwości (wieści o tym), co i teraz zostało powzięte jakkolwiek (byłoby to) oczywiste i niepodlegające wątpliwości, oraz zgodnie z Waszą nauką przez wszystkich duchownych pilnie strzeżone i podtrzymywane.

11. Nie dopuścimy przeto do tego, aby cokolwiek, co dotyczy pozycji Kościołów, jakkolwiek (byłoby to) oczywiste i niepodlegające wątpliwości, powzięte zostało bez wiedzy Waszej Świętobliwości, albowiem jesteście Głową wszystkich Świętych Kościołów. Przede wszystkim zatem, jak zostało powiedziane, spieszymy (w wysiłkach), aby Wasza Stolica wzrastała w czci i władzy.

12. Dajemy przeto do zrozumienia Waszej Świętobliwości, że nieliczni niewierni i dalecy od Świętego Bożego Katolickiego i Apostolskiego Kościoła odważyli się, wzorem Żydów, sprzeciwić temu, co zgodnie z Waszą nauką jest przez wszystkich duchownych pilnie zachowywane, wychwalane i głoszone. Zaprzeczają oni bowiem (temu), że Pan nasz Jezus Chrystus, jednorodzony Syn i Bóg nasz przyjął ciało z Ducha Świętego i świętej oraz pełnej łaski Dziewicy i Bożej rodzicielki Maryi stał się człowiekiem i został ukrzyżowany, że jest Jedyny w Świętej i Współistotnej Trójcy, godzien czci i chwały na równi z Ojcem i Duchem Świętym, 
secundum gratiam dicentes eum filium dei et alium dicentes deum verbum et alium Christum.

14. Omnes vero sacerdotes sanctae catholicae atque apostolicae ecclesiae et reverentissimi archimandritae sacrorum monasteriorum sequentes sanctitatem vestram et custodientes statum et unitatem sanctarum dei ecclesiarum, quam habent ad apostolicam vestrae sanctitatis sedem, nihil penitus immutantes de ecclesiastico statu, qui hactenus obtinuit atque obtinet, uno consensu confitentur et glorificant, praedicantes dominum nostrum Ihesum Christum, unigenitum filium et verbum dei et deum nostrum, ante saecula et sine tempore de patre natum, in ultimis diebus descendisse de caelis et incarnatum ex spiritu sancto et sancta atque gloriosa virgine et dei genetrice maria natum et hominem factum et crucifixum unum esse sanctae et consubstantialis trinitatis, coadorandum et conglorificandum patri et sancto spiritui.

15. Nec enim alium deum verbum et alium Christum cognoscimus, sed unum atque eundem ipsum consubstantialem patri secundum divinitatem et consubstantialem nobis eundem ipsum secundum humanitatem, passibilem carne, eundem ipsum impassibilem deitate.

16. Ut enim est in divinitate perfectus, ita idem ipse et in humanitate perfectus est: in una enim subsistentia unitatem suscipimus et confi-

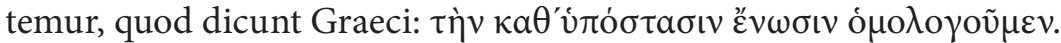

17. Et quoniam unigenitus filius et verbum dei, ante saecula et sine tempore de patre natus, idem ipse et in ultimis diebus descendens de caelis, incarnatus ex sancto spiritu et sancta atque gloriosa virgine et dei genetrice maria et homo factus, dominus noster Ihesus Christus proprie et vere deus est, ideo et sanctam et gloriosam virginem Mariam proprie et vere dei matrem dicimus: non quia deus verbum principium ex ipsa sumpserit, sed quod in ultimis diebus descendit de caelis et ex ipsa incarnatus et homo factus natus est.

18. Quem confitemur et credimus, sicut dictum est, consubstantialem esse patri secundum deitatem et consubstantialem nobis eundem ipsum secundum humanitatem, eiusdem miracula et passiones, quas sponte carne sustinuit, cognoscentes.

19. Suscipimus autem sancta quattuor concilia, id est trecentorum decem et octo sanctorum patrum, qui in Nicaea congregati sunt, et centum 
współistotny Ojcu poprzez (swoją) boskość, a nam współistotny poprzez (swoją) ludzkość, cierpiący ciałem, a nieznający cierpienia w boskości.

13. Wydaje się, że (ci) zaprzeczający wyznaniu, że Jezus Chrystus, Jednorodzony Syn Boży i Bóg nasz jest Jedyny w Świętej i Współistotnej Trójcy, podążają za błędną nauką Nestoriusza, twierdząc, że poprzez łaskę jest On Synem Bożym oraz że jednym jest Słowo Boga, innym zaś Chrystus.

14. Wszyscy zaś duchowni Świętego, Apostolskiego Kościoła i przewielebni archimandryci świętych monasterów podążający za Waszą Świętobliwością, strzegący pozycji Świętych Kościołów i jedności, którą mają (one) ze Stolicą Apostolską Waszej Świętobliwości, nie naruszając w żaden sposób pozycji Kościoła [powszechnego], którą do tej pory utrzymywał i (w dalszym ciągu) utrzymuje, jednogłośnie wyznają i oddają cześć, głosząc, że Pan Nasz Jezus Chrystus, jednorodzony Syn i Słowo Boga i Bóg nasz, przed wiekami, poza czasem z Ojca zrodzony, w ostatnich dniach zstąpił z niebios, przyjął ciało z Ducha Świętego i narodził się ze świętej oraz pełnej łaski Dziewicy, Bożej Rodzicielki Maryi i stał się człowiekiem i został ukrzyżowany, jest Jedyny w Świętej i Współistotnej Trójcy, godzien czci i chwały na równi z Ojcem i Duchem Świętym.

15. Nie wyznajemy przeto Słowa Bożego jako jednego, a Chrystusa jako drugiego, lecz jako jednego i tego samego, współistotnego Ojcu poprzez swoją Boską naturę i współistotnego nam przez swoją ludzką naturę cierpiący ciałem, a jednocześnie nieznającego cierpienia w (swojej) Boskiej naturze.

16. Jak bowiem jest pełen w swojej Boskiej naturze, tak samo i w ludzkiej naturze pozostaje pełny: uznajemy zatem i wyznajemy (Jego) jedność w jednym istnieniu, jak mówią Grecy; „Powszechnie uznajemy (Jego) jedność w istocie".

17. A ponieważ Jednorodzony Syn i Słowo Boga, przed wiekami, na początku czasów zrodzony z Ojca, ten sam, (który) w ostatnich dniach, zstępując z Niebios, przyjął ciało z Ducha Świętego i świętej oraz pełnej łaski Dziewicy i Bożej Rodzicielki Maryi i stał się człowiekiem, Pan nasz, Jezus Chrystus, rzeczywiście i prawdziwie jest Bogiem, zatem i świętą oraz pełną łaski Dziewicę Maryję rzeczywiście i prawdziwie nazywamy Bogurodzicą [Theotokos]: nie dlatego, że Bóg-Słowo wziął z Niej początek, lecz dlatego, że w ostatnich dniach zstąpił z Niebios i z Niej samej przyjąwszy ciało stał się człowiekiem i narodził się. 
quinquaginta sanctorum patrum, qui in hac regia urbe convenerunt, et sanctorum patrum, qui in Epheso primo congregati sunt, et sanctorum patrum, qui in Chalcedone convenerunt, sicut vestra apostolica sedes docet atque praedicat.

20. Omnes ergo sacerdotes sequentes doctrinam apostolicae vestrae sedis ita credunt et confitentur et praedicant.

21. Unde properavimus haec ad notitiam deferre vestrae sanctitatis per Hypatium et Demetrium, beatissimos episcopos, ut nec vestram sanctitatem lateat, quae a quibusdam paucis monachis male et iudaice secundum nestorii perfidiam denegata sunt.

22. Petimus ergo vestrum paternum adfectum, ut vestris ad nos destinatis litteris et ad sanctissimum episcopum huius almae urbis et patriarcham vestrum fratrem, quoniam et ipse per eosdem scripsit ad vestram sanctitatem festinans in omnibus sequi sedem apostolicam beatitudinis vestrae, manifestum nobis faciatis, quod omnes, qui praedicta recte confitentur, suscipit vestra sanctitas et eorum, qui iudaice ausi sunt rectam denegare fidem, condemnat perfidiam.

23. Plus enim ita et circa vos omnium amor et vestrae sedis crescit auctoritas et quae ad vos est unitas sanctarum ecclesiarum inturbata servabitur, quando per vos didicerint omnes beatissimi episcopi eorum, quae ad vos relata sunt, sinceram vestrae sanctitatis doctrinam. Petimus autem vestram beatitudinem orare pro nobis et dei nobis adquirere providentiam.

24. Et alia manu: divinitas te servet per multos annos, sancte ac religiosissime pater. Dat. VIII id. Iun. Constantinopoli dn. Iustiniano perpetuo Augusto III.

25. Liquet igitur, gloriosissime imperator, ut lectionis tenor et legatorum vestrorum relatio patefecit, vos apostolicis eruditionibus studere, cum de religionis catholicae fide ea sapitis, ea scripsistis, ea populis fidelibus publicastis, quae, sicut diximus, et sedes apostolica docet et patrum veneranda decrevit auctoritas et nos confirmavimus in omnibus.

26. Opportunum est ergo voce clamare prophetica: 'iucundetur caelum desuper, effundant montes iucunditatem et colles laetitia laetabuntur'. 
18. Świadomi Jego cudów i cierpienia, które dobrowolnie wziął na siebie w ciele, wyznajemy zatem i wierzymy, że jak zostało powiedziane, współistotny jest Ojcu przez (swoją) boskość i współistotny nam poprzez (swoją) ludzkość.

19. Uznajemy przeto cztery święte sobory [powszechne], to jest: trzystu osiemnastu świętych ojców, którzy zgromadzili się w Nicei [na Sobór w 325 r.], stu pięćdziesięciu świętych ojców, którzy przybyli do tego królewskiego miasta [na I Sobór w Konstantynopolu w 381 r.], świętych ojców, którzy najpierw zgromadzili się w Efezie na I Sobór w 431 r.], i świętych ojców, którzy przybyli do Chalcedonu [na Sobór w 451 r.], jak Wasza Stolica Apostolska naucza i głosi.

20. Tak przeto i wszyscy duchowni podążający za nauką Waszej Stolicy Apostolskiej wierzą, wyznają i głoszą.

21. Stąd też spieszymy donieść do wiadomości Waszej Świętobliwości poprzez Hypatiusza i Demetriusza, wielce błogosławionych biskupów, aby nie umknęło Waszej wiadomości co przez nielicznych mnichów, (postępujących) wzorem Żydów i według zła szerzonego przez Nestoriusza, zostało zakwestionowane.

22. Prosimy przeto, przez wzgląd na Waszą ojcowską miłość, abyście w Waszym liście przeznaczonym nam i Przeświętemu Biskupowi tego przesławnego miasta [Konstantynopola], Waszemu Bratu - jako że i on przez tych samych posłańców do Waszej Świętobliwości pisze, spiesząc, aby we wszystkim nadążać za Stolicą Apostolską Waszej Świętobliwości - dali nam do zrozumienia, że wszystkich, którzy to, co nakazane, należycie wyznają, Wasza Świętobliwość przyjmuje do siebie, zaś tych, którzy wzorem Żydów odrzucają wiarę, potępia.

23. Jeszcze bardziej wzrośnie zarówno miłość ludzi względem Was, jak i władza Waszej Stolicy, a jedność wszystkich Kościołów z Tobą pozostanie nienaruszona, gdy tylko wszyscy święci biskupi poznają przez Was prawdziwą naukę Waszej Świętobliwości, która została (w tym liście) opisana. Prosimy zatem, aby Wasza Świętobliwość modlił się za nami i wyprosił nam Bożą przychylność.

24. A inną ręką [dopisane własnoręcznie przez cesarza]: Niech Bóg ma Cię w swej opiece przez długie lata, Święty i Najpobożniejszy Ojcze. Nadano 6 czerwca w Konstantynopolu za III konsulatu Justyniana [533 r.], wiecznego Augusta 
27. Haec igitur in tabulis cordis fideles scribere, haec ut pupillas oculorum convenit observare.

28. Neque enim quisquam est, in quo Christi caritas fervet, qui tam rectae, tam verae confessionis vestrae fidei refragator existat, cum impietatem evidenter Nestorii Eutychisque et omnium haereticorum damnantes, unam veram catholicam fidem domini et dei nostri salvatoris Ihesu Christi magisterio institutam et propheticis apostolicisque praedicationibus ubique diffusam et sanctorum per totum orbem confessionibus roboratam, patrum atque doctorum sententiis adunatam et nostrae doctrinae consentaneam inconcusse atque inviolabiliter devota deo et pia mente servatis.

29. Soli etenim vestris professionibus adversantur, de quibus divina scriptura loquitur dicens: 'posuerunt mendacium spem suam et mendacio operiri speraverunt': et iterum qui secundum prophetam dicunt domino: 'recede a nobis, vias tuas scire nolumus', propter quos Salomon dicit: 'semitas propriae culturae erraverunt, colligunt autem manibus infructuosa'.

30. Haec est igitur vestra vera fides, haec certa religio, hoc beatae recordationis, ut diximus, patres omnes praesulesque romanae ecclesiae, quos in omnibus sequimur, hoc sedes apostolica praedicavit hactenus et inconvulse custodivit: huic confessioni, huic fidei quisquis contradictor extiterit, alienum a sancta communione, alienum se ipse ab ecclesia iudicavit esse catholica.

31. Nos enim in Romana Cyrum cum sequacibus suis invenimus civitate, qui de acoemetensi monasterio fuit, quos apostolicis suasionibus ad rectam fidem et velut oves, quae perierant errantes, ad ovile contendimus revocare dominicum, ut agnoscerent secundum prophetam linguae balbutientes loqui quae ad pacem sunt.

32. Non credentibus autem per nos primus apostolorum Esaiae prophetae verba dicit: 'pergite lumini ignis vestri et flammae, quam accendistis'. Sed obduratum est cor eorum, ut scriptum est, ut non intellegerent, et pastoris vocem oves, quae meae non erant, audire minime voluerunt.

33. In quibus servantes ea, quae ab ipsorum sunt statuta pontifice, eos minime in nostra communione recepimus et ab omni ecclesia catholica 
25. Jest przeto jasne, Najłaskawszy Władco, co zresztą wynika z treści Waszego listu oraz przekazu Waszych posłów, że sprzyjacie naukom apostolskim, skoro o religii katolickiej (sam) to wiesz, to napisałeś, to wiernemu ludowi przedstawiłeś, czego tak jak powiedzieliśmy, zarówno Stolica Apostolska naucza, czcigodny autorytet ojców Kościoła uchwalił, jak i my w całości potwierdzamy.

26. Stosowne jest przeto wołać głosem proroczym: „Niech się cieszą niebiosa w górze, niech góry rozstąpią się z radości i pagórki z weselem się radują".

27. Te (słowa) przeto niech zostaną wyryte na tabliczkach Waszych wiernych serc, niech będą strzeżone jak źrenice oczu.

28. Nie ma bowiem nikogo, w kim płonęłaby miłość Chrystusa, a kto odrzuciłby tak prawdziwe wyznanie Waszej wiary. Wyraźnie potępiając bezbożność Nestoriusza i Eutychesa i wszystkich (innych) heretyków, przy pomocy swojego poświęconego Bogu i łaskawego umysłu zachowałeś bez uszczerbku jedyną prawdziwą katolicką wiarę nauczaniem Pana naszego i Zbawiciela Jezusa Chrystusa ukutą, przepowiadaniem proroków i apostołów wszędzie rozprzestrzenioną, świadectwami świętych na całym świecie umocnioną, pismami ojców i doktorów (Kościoła) w jedno zebraną, a za sprawą naszej nauki stosowną.

29. Wszakże tylko oni sprzeciwiają się Waszym wyznaniom (wiary), ci, o których traktuje Pismo Święte, mówiąc „Uczynili z kłamstwa swoją nadzieję i oczekiwali, że w kłamstwie się ukryją” [Iz 28,15]. I dalej, co według proroka mówią do Boga: „Odstąp od nas, dróg twoich znać nie chcemy” [Hi 21,14]. Salomon zaś mówi o nich: „Pomylili drogi własnych upraw, zbierać będą zatem rękami swymi bezowocnie”.

30. To jest przeto Wasza prawdziwa wiara, to niewzruszona religia, tego, jak powiedzieliśmy, wszyscy świętej pamięci ojcowie i zwierzchnicy Kościoła Rzymskiego, których we wszystkim naśladujemy, tego (i) Stolica Apostolska do tej pory nauczała i strzegła, aby pozostało nienaruszone: ktokolwiek sprzeciwił się temu wyznaniu i tej wierze, sam siebie osądził wrogiem Komunii Świętej, wrogiem Kościoła katolickiego.

31. My zaś natrafiliśmy w Rzymie na Cyrusa z klasztoru Akemetów z jego orszakiem, toteż spróbowaliśmy (ich) poprzez apostolskie namowy przywołać do właściwej wiary - jak owce, które zbłądziły, przywołuje się 
esse iussimus alienos, nisi errore damnato doctrinam nostram quantocius sequi habita regulari professione signaverint.

34. Aequum quippe est, ut, qui nostris minime oboedientiam commodant statutis, ecclesiis habeantur extorres.

35. Sed quia gremium suum numquam redeuntibus claudit ecclesia, obsecro clementiam vestram, ut, si proprio errore deposito et prava intentione depulsa ad unitatem ecclesiae reverti voluerint, in nostra communione receptis indignationis vestrae removeatis aculeos et nobis intercedentibus benigni animi gratiam condonate.

36. Deum autem et salvatorem nostrum Ihesum Christum exoramus, quatenus longaevis et pacificis vos dignetur custodire temporibus in hac vera religione et unitate et veneratione apostolicae sedis, cuius principatum ut christianissimi et pii conservatis in omnibus.

37. Praeterea, serenissime principum, laudamus legatorum vestrorum personas, Hypatii et Demetrii fratrum et coepiscoporum nostrorum, quos clementiae vestrae gratos fore ipsa manifestavit electio.

38. Nam tantae causae pondus non nisi perfectis in Christo potuisset iis iniungi, tantae vero pietatis, tantae reverentiae plenos adfatus nisi per amantes minime dignaremini destinare.

39. Et alia manu: Gratia domini nostri Ihesu Christi et caritas dei patris et communicatio spiritus sancti sit semper vobiscum, piissime fili. Item subscriptio: Omnipotens deus regnum et salutem vestram perpetua protectione custodiat, gloriosissime et clementissime fili imperator Auguste. D. VIII K. April. Roma dn. Iustiniano pp. A. IIII et Paulino Iuniore vc. conss. 
na pastwisko pana - aby jak mówi prorok [Iz 32,4], nauczyli się swoimi bełkoczącymi językami mówić (rzeczy), które prowadzą do pokoju.

32. Do niewierzących mówi przeto przez nas Pierwszy Apostoł słowami proroka Izajasza „Idźcie w świetle ognia i płomieni, które rozpaliliście" [Iz 50,11], lecz jak zostało napisane, zatwardziałe są ich serca [Iz 6,10], toteż nie zrozumieli; owce, które nie były moje, nie chciały usłyszeć głosu pasterza.

33. Zachowując w stosunku do nich to, co przez ich własnego pontyfika zostało ustanowione, nie przyjęliśmy ich do naszej wspólnoty i nakazaliśmy im opuścić wszystkie Kościoły katolickie, jeśli nie przyznają się do błędu, jakim jest potępianie naszej doktryny i natychmiast nie potwierdzą na piśmie, że przestrzegają powszechnego wyznania.

34. Oczywiste jest również, że ci, którzy nie okażą posłuszeństwa naszym konstytucjom, zostaną wygnani z Kościołów.

35. Lecz jako że Kościół nigdy nie zamyka swojego łona przed tymi, którzy na nie powracają, błagam Waszą Łaskawość, jeśli przyznawszy się do swojego błędu i odrzuciwszy przewrotne zamiary, zechcieliby (oni) zostać przywróceni do jedności z Kościołem, abyście od przyjętych (na nowo) do Naszej wspólnoty odsunęli ostrza Waszego gniewu i za naszym pośrednictwem ofiarowali im łaskę ze swej łagodnej duszy.

36. Błagamy przeto Boga i Zbawcę naszego Jezusa Chrystusa, aby zechciał mieć Was w opiece przez długie i spokojne lata, w tej prawdziwej wierze, czci i jedności ze Stolicą Apostolską, której najwyższą godność, jak najbardziej chrześcijańscy i najpobożniejsi, zachowaliście we wszystkich (sprawach).

37. Ponadto, Najjaśniejszy z Władców, pragniemy pochwalić osoby Waszych posłów, Hypatiusza i Demetriusza, braci i współbiskupów naszych. Ich wybór dowiódł, że okażą oni wdzięczność Waszej Mądrości.

38. Ponieważ ciężaru takiej wagi nie moglibyście nałożyć na nikogo, kto nie byłby doskonałym w Chrystusie, nie poczytalibyście za godne posłania pism pełnych tak prawdziwej pobożności i tak wielkiego szacunku inaczej, niż poprzez tych, którzy (Was) miłują.

39. A inną ręką. [Dopisane własnoręcznie przez papieża] Łaska Pana Naszego Jezusa Chrystusa, miłość Boga Ojca i dary Ducha Świętego niech będą zawsze z Wami, Najpobożniejszy Synu. Również dopisek. 
Bóg Wszechmogący niech Twego panowania i zdrowia strzeże, otaczając je wieczną opieką. Nadano 25 marca w Rzymie, za czwartego konsulatu Pana naszego Justyniana, Wiecznego Augusta i Paulina Młodszego [534 r.].

\section{KOMENTARZ}

Analizę tekstu warto przeprowadzić w porządku chronologicznym. W związku z jego specyficznym układem oznacza to konieczność zaczęcia właściwie od środka - od miejsca, w którym papież przywołuje treść listu cesarza. Justynian, po stosunkowo obszernym wstępie mającym na celu wyrażenie jego poważania dla Stolicy Apostolskiej, płynnie przechodzi do właściwego powodu, dla którego zwraca się do Jana II. Są nim, jak sam mówi, „nieliczni niewierni”, którzy odważyli się sprzeciwić nauce Kościoła. Jak ma się niebawem okazać, nie są oni wcale tak nieliczni, bowiem cesarz w swoim liście wymienia kilka różnych od siebie herezji, a co za tym idzie, różnych grup heretyków. Mianem niewiernych Justynian określa tych, którzy zaprzeczają przytoczonej przez niego i powtórzonej aż trzykrotnie formule zawierającej najważniejsze prawdy wiary. Stanowi ona podsumowanie najistotniejszych postanowień czterech soborów powszechnych. Żeby się o tym przekonać, wystarczy porównać ją z tekstem wyznania wiary przyjętego na soborze w Konstantynopolu. Jednakże konstantynopolitańskie wyznanie wiary, w przeciwieństwie do Justyniana, wcale nie kładzie wielkiego nacisku na osobę Maryi jako Bogarodzicy ani też na kwestię dwóch natur Chrystusa. Dzieje się tak z tej przyczyny, że owe pojęcia dotyczą kontrowersji, które zostały rozstrzygnięte dopiero przez dwa następne sobory powszechne, kolejno: sobór w Efezie z 431 r. i sobór w Chalcedonie w $451 \mathrm{r}$. Cesarz poniekąd sam o tym wspomina, kiedy pod koniec swojego pisma zaznacza, że zgodnie z nauką Stolicy Apostolskiej uznaje „cztery święte sobory”, a więc również ich postanowienia.

Choć może się wydawać, że list cesarza jest dość obszerny jak na temat, który porusza, w gruncie rzeczy zawiera on niezwykle zwięzłe

$1 \quad$ Par. 19. 
podsumowanie największych sporów doktrynalnych w historii ówczesnego Kościoła. Z oczywistych względów koncentruje się przede wszystkim na tych, które były mu współczesne, wszak, jak sam twierdzi, kieruje nim chęć dążenia do jedności Kościoła i jedności z Kościołem. Dlatego też opisując „heretyków”, skupia się przede wszystkim na dwóch ich grupach: zwolennikach nestorianizmu i monofizytyzmu. Pomimo że Nestoriusz, którego imię niejednokrotnie pojawia się w tekście, został pozbawiony urzędu już w 433 r. ${ }^{2}$, czyli dokładnie 100 lat przed powstaniem opisywanego tutaj listu, a przyjęte przez Kościół anatemy Cyryla Aleksandryjskiego ${ }^{3}$ bezpośrednio przesądzały o niezgodności głoszonej przez niego doktryny z katolickim nauczaniem, w czasach Justyniana nadal nie brakowało mu zwolenników. Herezja Nestoriusza, jak nazywa ją cesarz, dotyczyła sporu chrystologicznego skupiającego się na osobie matki Jezusa ${ }^{4}$. Spór ten zmusił Teodozjusza II do zwołania soboru w Efezie ${ }^{5}$ i został ostatecznie zakończony uznaniem Maryi za Bogurodzicę (Theotokos) oraz wspomnianym już wyżej potępieniem tych, którzy twierdziliby inaczej.

Kolejną grupą, która według władcy Konstantynopola szczególnie uderzała w interesy jedności Kościoła, byli monofizyci, czyli zwolennicy nauczania Eutychesa ${ }^{6}$, archimandryty z Konstantynopola, który nie zgadzał się, jakoby Chrystus miał jednocześnie dwie natury ${ }^{7}$.

Obawy, które Justynian żywił wobec monofizytów, nie były wcale irracjonalne. Stanowili oni przecież znacznie większą i potężniejszą grupę niż wyodrębnieni już wcześniej nestorianie ${ }^{8}$.

W rezultacie sporów doktrynalnych IV i V w. jedność Kościoła, o której z wielkim zaangażowaniem wypowiada się cesarz, została poddana ogromnej próbie. Ostatni z soborów powszechnych, sobór chalcedoński,

\footnotetext{
2 DSP, I, s. 159.

3 Ibidem, s. 153-158.

4 E. Wipszycka, Kościół w świecie późnego antyku, Warszawa 2017, s. 196.

5 J. Gaudemet, L'Eglise dans l'Empire Romain, Paris 1958, s. 606.

6 H. Chadwick, Kościół w epoce wczesnego chrześcijaństwa, Warszawa 2004,
} s. 199-204.

7 DSP, I, s. 196-213 (Tomus ad Flavianum).

8 M. Starowieyski, Sobory niepodzielonego Kościoła, Kraków 2016, s. 103. 
miał dla Cesarstwa Wschodniego jeszcze dodatkowe znaczenie. To właśnie jednemu z jego kanonów zawdzięczało ono szczególną pozycję Konstantynopola w hierarchii kościelnej. Chodzi oczywiście o kanon $28^{9}$, który uchwałą o przywilejach stolicy Konstantynopola nadał mu miano Nowego Rzymu. I ten wątek pojawia się, choć już nie bezpośrednio, $\mathrm{w}$ korespondencji cesarza $\mathrm{z}$ papieżem. Wbrew pozorom to wcale nie Justynian określa w niej stolicę Wschodu mianem Nova Roma. Robi to Jan II. Odnosząc się do Rzymu i Konstantynopola poprzez zaimek utraque - obie, w domyśle - stolice ${ }^{10}$, milcząco uznaje wysoką pozycję stolicy Cesarstwa w kontekście nie politycznym - tu prymat Konstantynopola nie ulegał nawet najmniejszej wątpliwości, ale religijnym.

Te wszystkie poruszone problemy nie dostarczają jednak jeszcze dostatecznego wyjaśnienia powodów, dla których kwestie wiary miałyby zostać uregulowane w kodeksie będącym źródłem prawa powszechnie obowiązującego. Dlaczego więc miało to miejsce? Odpowiedź na to pytanie zdaje się wynikać z charakteru polityki, jaką prowadził Justynian. Nie był on oczywiście pierwszym cesarzem ingerującym w sprawy Kościoła. W tej materii znacznie wyprzedzał go Konstantyn Wielki, to on zwołał sobór nicejski - pierwszy z soborów powszechnych, a także, jako pierwszy chrześcijański władca ${ }^{11}$, zapewniał Kościołowi liczne przywileje $^{12}$. Podobnie i kolejny „Wielki”, cesarz Teodozjusz, którego w tak istotnym miejscu na kartach historii zapisała w dużej mierze właśnie polityka religijna. Nie tylko ze względu na to, że za jego sprawą zebrał się kolejny z soborów powszechnych, wspomniany już niejednokrotnie sobór konstantynopolitański I. Teodozjusza wyróżniło też to, że zajął się herezjami od strony formalnej.

Wprowadził pojęcie herezji do legislacji i opatrzył sankcjami wszelkie formy sprzeciwu wobec powszechnie przyjętego ${ }^{13}$ nauczania Kościoła.

9 DSP, I, s. 250.

10 J. Gaudemet, L'Eglise..., s. 413.

11 A. ZıóŁкоwsкi, Historia powszechna. Starożytność, Warszawa 2009, s. 914-915.

12 E. Wipszycka, The Alexandrian Church People and Institutions "Journal of Juristic Papyrology» Supplement 25/2015, s. 72-76.

13 Zarówno w tym kontekście, jak i w całej pracy pojęcie „powszechny” odnosi się bezpośrednio do nauczania Kościoła uformowanego na podstawie postanowień 
To właśnie na mocy jego edyktów chrześcijanie pozostający w niezgodzie z ostatecznie wyjaśnioną na soborze kwestią współistotności natur Chrystusa nie mogli sprawować kultu w miastach ${ }^{14}$. Nie sposób nie wspomnieć o najsławniejszym z nich, cunctos populos, znanym również pod nazwą edyktu tesalońskiego, który cesarz, a właściwie cesarze formalnie autorami edyktu byli oprócz Teodozjusza Gracjan i Walentynian, skierowali do „ludności miasta Konstantynopola”15. Prawo, które w nim proklamują, to nic innego jak uznanie współistotności Trzech Osób Boskich w Trójcy Świętej, na podstawie nauczania apostolskiego i doktryny Ewangelii. Swój cesarski autorytet podpierają też osobami najwyższego kapłana (papieża) Damazego oraz biskupa Aleksandrii, Piotra, którzy także reprezentują „właściwy” pogląd w regulowanej kwestii. Na mocy edyktu ci wyznawcy, którzy okażą się wierni nauce o Trójcy, mogą nazywać się chrześcijanami, katolikami, natomiast pozostali zostają pozbawieni możliwości identyfikowania się z Kościołem. Prawo to przetrwało do VI w., kiedy to Justynian inkorporował ów edykt do swojego kodeksu (CJ 1.1.1).

Nie ma tu miejsca na opisywanie kompletnej ewolucji relacji Cesarstwa z Kościołem między IV a VI w. Warto jednak zwrócić uwagę na to, jak bardzo podobne są, nawet na poziomie swojej formy, regulacje prawne dotyczące religii Teodozjusza I do tych Justyniańskich, wydanych niemal wiek później. Relewantne są w nich takie elementy jak:

soborów powszechnych. Nie można tego słowa rozumieć w jego dzisiejszym znaczeniu, bowiem skala sporów doktrynalnych była zbyt duża, aby mówić o faktycznej jedności chrześcijańskiego nauczania.

14 A. ZióŁKowski, Historia..., s. 922.

15 C.J. 1.1.1: cunctos populos, quos Clementiae Nostrae regit temperamentum, in tali volumus religione versari, quam Divinum Petrum Apostolum tradidisse Romanis, religio usque nunc ab ipso insinuata declarat: quamque Pontificem Damasum sequi caret et Petrum Alexandriae Episcopum, virum apostolicae sanctitatis: ut secundum apostolicam disciplinam evangelicamque doctrinam Patris et Filii et Spiritus Sancti unam deitarem sub parili maiestate et sub pia Trinitate credamus. hanc legem loquentes Christianorum Catholicorum nomen iubemus amplecti: reliquos vero dementes vaesanosque iudicantes haeretici dogmatis infamiam sustinere: [nec conciliabula suorum Ecclesiarum nomen accipere: C.Th. 16.1.2], divina primum vindicta, post etiam motus nostri, quem ex caelesti arbitrio sumpserimus, ultione plectendos. 
odwołanie do tradycji apostolskiej, powołanie się na autorytet hierarchów oraz, co chyba najważniejsze, potępienie niewiernych. Działanie Justyniana nie było więc ani czymś oderwanym od historycznego kontekstu, ani też nie stanowiło odstępstwa od powszechnej praktyki władców. Fakt, że pozwolił sobie na tak głęboką ingerencję w sprawy Kościoła, wynikał ze stopniowego procesu kumulacji w cesarskim ręku władzy świeckiej i religijnej. Nawet i to nie stanowiło w zasadzie novum; już z okresu pryncypatu znana jest praktyka przybierania przez władcę najwyższego urzędu kapłańskiego (pontifex maximus), a więc sprawowania władzy jednocześnie w dwóch najistotniejszych sferach. W tym przypadku mamy mimo wszystko do czynienia z nieco inną sytuacją; funkcje cesarza i papieża pozostawały rozdzielone nie tylko na dwie różne osoby, ale i na dwa różne kontynenty.

Fizyczna odległość Stolicy Apostolskiej mogła, ale nie musiała, być dla chrześcijańskich cesarzy asumptem do uzurpacji władzy również w zakresie spraw wiary. Faktem jest natomiast, że kumulacja władzy świeckiej i kościelnej osiągnęła swój szczyt wraz z rozpoczęciem panowania Justyniana. List opublikowany w VIII rozdziale I tytułu I księgi Corpus Iuris Civilis jest tego idealnym potwierdzeniem. Zawiera w sobie nie tylko zarys stosunków stolicy Cesarstwa ze Stolicą Apostolską, lecz także przekazany między słowami obraz polityki religijnej Justyniana. Ustawodawstwo bezpośrednio dotyczące wiary chrześcijańskiej służyło zagwarantowaniu jedności religijnej, a co za tym idzie, jedności samego państwa, bowiem wszelkie rozłamy w Kościele mogły zagrozić również autorytetowi władzy świeckiej ${ }^{16}$. Można więc wykorzystać współczesną koncepcję prawa wyznaniowego ${ }^{17} \mathrm{w}$ celu opisania i zidentyfikowania relacji między państwem - Cesarstwem a Kościołem - Stolicą Apostolską. Cezaropapizm, rozwijający się prężnie począwszy od końca IV w., a ostatecznie ukształtowany podczas panowania Justyniana, jest

16 A. DęBIński, Kościół i prawo rzymskie, Lublin 2007, s. 35.

17 M. Pietrzak (Prawo wyznaniowe, Warszawa 2013, s. 14-15) definiuje prawo wyznaniowe jako kompleks norm wydanych lub uznanych przez państwo, określających sytuację jednostki ze względu na jej wyznanie, regulujących stosunek państwa do związków wyznaniowych oraz reglamentujących różnorodne przejawy ich działalności, które stanowią część państwowego systemu prawnego. 
figurą dokładnie definiującą te relacje. To właśnie on doprowadził do zespolenia Kościoła z państwem oraz sprawił, że niegdyś odrębne ius sacrum stało się częścią ius publicum ${ }^{18}$.

\section{Literatura}

Baron A., Pietras H. (red.), Dokumenty soborów powszechnych, Kraków 2002.

CHADwick H., Kościół w epoce wczesnego chrześcijaństwa, Warszawa 2004.

DęBı́nski A., Kościót i prawo rzymskie, Lublin 2007.

Gaudemet J., L'Eglise dans l'Empire Romain, Paris 1958.

Pietrzak M., Prawo wyznaniowe, Warszawa 2013.

Starowieyski M., Sobory niepodzielonego Kościoła, Kraków 2016.

Wipszycka E., Kościół w świecie późnego antyku, Warszawa 2017.

Wipszycka E., The Alexandrian Church people and institutions, "The Journal of Juristic Papyrology» Supplement 25/2015, s. 72-76.

ZıóŁkowski A., Historia powszechna. Starożytność, Warszawa 2009.

$18 \quad$ Ibidem, s. 57. 